\title{
CYTOMEGALOVIRUS REACTIVATION IN PATIENTS TREATED WITH ALLOGENEIC HEMATOPOIETIC STEM CELL TRANSPLANTATION
}

\section{Jovana Lina Kessler ${ }^{1}$, Katarina Ivanović ${ }^{1}$, Dejana Stanisavljević ${ }^{1,2}$, Milena Todorović Balint ${ }^{1,3}$}

\author{
1 Faculty of Medicine, University of Belgrade, Belgrade, Serbia \\ 2 Faculty of Medicine, University of Belgrade, Belgrade, Serbia \\ 3 Institute of Public Health of Serbia "Dr Milan Jovanović Batut"
}

\author{
Medicinski fakultet Univerziteta u Beogradu, Beograd, Srbija \\ 2 Institut za medicinsku statistiku i informatiku, Beograd, Srbija \\ 3 Klinika za hematologiju, Univerzitetski klinički centar Srbije, \\ Beograd, Srbija
}

\section{SAŽETAK}

Uvod: Oportunistička CMV reaktivacija je najčešća virusna komplikacija nakon alogene transplantacije matičnih ćelija hematopoeze (AloTMĆH).

Cilj: Cilj rada je da se ispita učestalost CMV reaktivacije u odnosu na serostatus donora i recipijenta, kao i korelacija sa danom postizanja engraftmenta leukocita (Le) i trombocita (Tr). Analizirano je da li je veća učestalost CMV reaktivacije kod MAC (myeloablative conditioning) ili RIC (reduced intensity conditioning) režima i da li je učestalost veća kod srodne (MRD, match related donor) ili nesrodne (MUD, match unrelated donor) aloTMĆH. Analizirali smo da li CMV reaktivacija utiče na preživljavanje nakon alogene TMĆH.

Materijal i metode: $U$ retrospektivnoj kohortnoj studiji, ispitivana su 42 bolesnika, starosti preko 18 godina, lečenih na Klinici za hematologiju Univerzitetskog kliničkog centra Srbije (UKCS) od decembra 2017. do novembra 2019. godine.

Rezultati: Najveća učestalost reaktivacije je bila u grupi u kojoj je recipijent (R) bio seropozitivan a donor (D) seronegativan ( $\mathrm{R}+/ \mathrm{D}-=60,0 \%)$. Broj kopija CMV DNK korelira sa danom engraftmenta Le $(p=0,031)$, ali ne i sa engraftmentom $\operatorname{Tr}(p=0,598)$. Učestalost reaktivacije kod pacijenata podvrgnutih RIC-u je $25,0 \%$, a $63,5 \%$ kod pacijenata podvrgnutih MAC-u. Jačina režima korelira sa brojem kopija CMV DNK $(p=0,025)$. Korelacija između tipa transplantacije (MRD ili MUD) i reaktivacije CMV infekcije nije utvrđena $(p=0,515)$. Sveukupno preživljavanje je bilo 36,39 meseci (95\% Cl 26,0 - 46,78). Srednja vrednost preživljavanja nakon transplantacije, ukoliko se desila reaktivacija, iznosilo je 7,39 meseci (95\% Cl 5,72

Zaključak: CMV reaktivacija nije povezana sa povećanjem mortaliteta u ispitivanoj grupi bolesnika nakon aloTMĆH i bila je najčešća u kombinaciji R+D-

Ključne reči: alogena transplantacija matičnih ćelija hematopoeze, CMV reaktivacija -9,06), ali nismo dokazali da CMV reaktivacija utiče na preživljavanje $(p=0,527)$.

\begin{abstract}
Introduction: Opportunistic CMV reactivation is the most common viral complication after allogenic hematopoietic stem cell transplantation (allo-HSCT).

Aim: The aim of our study is to evaluate the frequency of CMV reactivation in relation to the serostatus od the donor and the recipient, and the correlation with the day of leukocyte (Le) and thrombocyte (Tr) engraftment. We compared the frequency of CMV reactivation in myeloablative conditioning (MAC) versus reduced intensity conditioning (RIC), as well as in match related donor (MRD) versus match unrelated donor (MUD) allo-HSCT. We analyzed whether CMV reactivation affected the overall survival (OS) after allo-HSCT.
\end{abstract}

Materials and methods: In a retrospective cohort study, we inspected 42 patients over the age of 18 years, who were treated at the Clinic for Hematology of the Clinical Center of Serbia, from December 2017 to November 2019.

Results: Most CMV reactivations were noticed if the recipient ( $\mathrm{R}$ ) was seropositive, and the donor (D) was seronegative ( $R+/ D-=60.0 \%)$. The number of CMV DNA copies corelated with the day of leukocyte engraftment of $(p=0.031)$, but not of thrombocyte engraftment $(p=0.598)$. The frequency of reactivation in patients treated with RIC was $25.0 \%$, and it was $63.5 \%$, if they were treated with MAC. The intensity of the conditioning regimen corelated with the number of CMV DNA copies $(p=0.025 \%$ ). There was no correlation found between the type of transplantation (MRD or MUD) and CMV reactivation ( $p=0.515)$. 0 S after allo-HSCT was 36.39 months ( $95 \% \mathrm{Cl} 26,0-46,78)$. The mean OS in patients with CMV reactivation was 7.39 months $(95 \% \mathrm{Cl} 5,72-9,06)$, but we did not prove that CMV reactivation had an impact on $0 S(p=0.527)$.

Conclusion: CMV reactivation was most common in the $\mathrm{R}+/ \mathrm{D}-$ group. CMV reactivation did not affect $\mathrm{OS}$ after allo-HSCT in our group of patients.

Key words: allogeneic hematopoietic stem cell transplantation, CMV reactivation

\section{Corresponding author:}

Jovana Lina Kessler

Faculty of Medicine, University of Belgrade, Serbia

229 Bulevar kralja Aleksandra Street, 11000 Belgrade, Serbia

E-mail:jovanalinakessler@gmail.com

Bulevar kralja Aleksandra 229, 11000 Beograd, Srbija

E-mail: jovanalinakessler@gmail.com

Primljeno • Received: May 17, 2021;

Revidirano - Revised: May 21, 2021;
Prihvaćeno - Accepted: May 25, 2021;

Online first: June 25, 2021. 


\section{UVOD}

Citomegalovirus (CMV) je ubikvitarni herpes virus, koji je naziv dobio po tome što su inficirane ćelije uvećane, odnosno citomegalične.

Prevalencija CMV seropozitivnosti varira u svetu od $60 \%$ do $100 \%$. Do primarne infekcije najčešće dolazi u ranom detinjstvu, i u največem broju slučajeva je asimptomatska, a može se ispoljiti i u formi atipične mononukleoze [1]. Nakon primarne infekcije, genom CMV virusa perzistira u genomu ćelija domaćina, ne produkujući virusne partikule, odnosno ostaje u latentnom stanju, zadržavajući mogućnost reaktivacije usled imunokompromitovanosti domaćina.

Alogena transplantacija matičnih ćelija hematopoeze (aloTMĆH) podrazumeva zamenu i repopulaciju matičnih ćelija hematopoeze primaoca, matičnim ćelijama donora. Najčešće indikacije za sprovođenje ove procedure lečenja su akutne leukemije, mijelodisplastični sindromi, aplastična anemija, urođene bolesti metabolizma i autoimunske bolesti. Donori su HLA identični (rođeni brat i sestra) ili haploidentični srodnici, ili davalac može biti nesrodan HLA podudaran ili delimično podudaran $[2,3]$.

Morbiditet i mortalitet nakon aloTMĆH zavise od stope relapsa bolesti, kao i od mortaliteta nevezanog za relaps bolesti (non-relapse mortality - NRM). Sve su značajniji uzroci NRM-a nakon alogene TMĆH, koji iznosi $10-30 \%[4,5]$, a u njih spadaju infekcije, disfunkcija organa, kao i bolest kalema protiv domaćina (engl. graft versus host disease - GvDH) [6]. Najčešće infekcije su infekcije krvi sa incidencijom koja može da varira od $20 \%-70 \%$ [7].

Imunska reaktivnost primalaca koštane srži ili organa je veštački suprimirana imunosupresivnom terapijom kako bi se sprečilo odbacivanje grafta, tako da su oni u visokom riziku za reaktivaciju različitih latentnih virusnih infekcija. Oportunistička CMV reaktivacija je najčešća virusna komplikacija nakon aloTMĆH, zbog čega se rutinski određuje DNK viremija kvantitativnom $P C R$ metodom, jednom do dva puta nedeljno, u prvih 100 dana nakon transplantacije [8]. Verovatnoća i učestalost reaktivacije zavisi od serostatusa donora (D) i recipijenta (R). Reaktivacija se dešava kod $60 \%$ seronegativnih i 10\% seropozitivnih recipijenata, koji su graft dobili od seropozitivnih donora [8,9]. Međutim, najveća incidencija reaktivacije se beleži kod seropozitivnih recipijenata, koji su graft dobili od seronegativnog donora $[8,10]$. Osim serostatusa donora i recipijenta, kao faktor rizika navode se i starija životna dob pacijenata, HLA nepodudarnost ili nesrodni donor, deplecija T ćelija, bolest kalema protiv domaćina $(G v H D)$ i visoke doze kortikosteroida u terapiji GvHD [8]. Manifestacije CMV bolesti su: pneumonija, hepatitis, gastroenteritis,

\section{INTRODUCTION}

The cytomegalovirus (CMV) is a ubiquitous herpes virus, whose name stems from the enlargement of the infected cells, i.e., they are cytomegalic.

The prevalence of CMV seropositivity varies in the world from $60 \%$ do $100 \%$. Primary infection usually occurs in early childhood, and in most cases, it is asymptomatic, though it can manifest in the form of atypical mononucleosis [1]. After primary infection, the genome of the CMV virus persists in the genome of the host, without producing viral particles, i.e., it remains latent, maintaining the possibility of reactivation, if the host is immunocompromised.

Allogenic hematopoietic stem cell transplantation (allo-HSCT) is the replacement and repopulation of the recipient's hematopoietic stem cells with the stem cells of the donor. The most common indications for carrying out this therapeutic procedure are acute leukemias, myelodysplastic syndromes, aplastic anemia, congenital metabolic disorders, and autoimmune diseases. The donors are HLA identical (brother or sister), or haploidentical relatives, or the donor can be unrelated HLA-matching or partially matching [2,3].

Morbidity and mortality upon allo-HSCT depend on the relapse rate of the disease, as well as on mortality unrelated to the relapse of the disease (non-relapse mortality - NRM). There is a growing significance of the causes of NRM after allo-HSCT, which is $10-30 \%$ $[4,5]$, and amongst these causes are infections, organ dysfunction, as well as graft versus host disease (GvDH) [6]. The most common infections are blood infections with an incidence that can vary from $20 \%-70 \%$ [7].

Immune reactivity of recipients of bone marrow or organs is artificially suppressed with immunosuppressive therapy, in order to prevent graft rejection, which is why these patients are at high risk of the reactivation of different latent viral infections. Opportunistic CMV reactivation is the most common viral complication after allo-HSCT, which is why DNA viremia is determined with the quantitative PCR method, once to twice a week, in the first 100 days after transplantation [8]. The probability and frequency of reactivation depends on the serostatus of the donor (D) and the recipient (R). Reactivation happens in $60 \%$ of seronegative and $10 \%$ of seropositive recipients who received their graft from seropositive donors $[8,9]$. However, the highest reactivation incidence is recorded in seropositive recipients who received their graft from a seronegative donor $[8,10]$. Apart from the serostatus of the donor and recipient, the following are also described as risk factors: older age of the patients, unmatching HLA or unrelated donor, T-cell depletion, graft versus host disease (GvHD) and high doses of corticosteroids in GvHD 
retinitis i encefalitis, pri čemu se bolest može razviti kao rana ili kasna komplikacija nakon procedure [11].

Sve veći uspeh antivirusne terapije je smanjio incidenciju CMV bolesti na približno $10 \%$ u prvoj godini nakon transplantacije, ali se zato uvećala incidencija kasnih CMV reaktivacija, zato što je utvrđeno da antivirusna terapija usporava oporavljanje T specifičnog odgovora na CMV. Mortalitet od CMV pneumonije je i dalje visok, oko $70 \%$, dok se CMV bolest gastrointestinalnog trakta može ispoljiti bez detektabilne viremije, zbog čega se teško razlikuje od GvHD gastrointestinalnog trakta [12].

U literaturi su navedeni podaci o zaštitnom dejstvu rane CMV reaktivacije od relapsa mijeloidne leukemije, ali isto nije dokazano za druge hematološke neoplazme [13].

$\mathrm{U}$ ovom radu smo upoređivali CMV reaktivaciju u odnosu na serostatus donora i recipijenta (D/R) i ispitali da li postoji korelacija CMV statusa sa danom postizanja engraftmenta Le i Tr. Analizirano je da li je veća učestalost CMV reaktivacije kod MAC (myeloablative conditioning) ili RIC (reduced intensity conditioning) režima i da li je veća učestalost kod srodne (match related donor, MRD) ili nesrodne (match unrelated donor, MUD) aloTMĆH. Cilj nam je takođe bio da utvrdimo da li CMV reaktivacija utiče na preživljavanje nakon aloTMĆH.

\section{METODE}

U retrospektivnoj kohortnoj studiji, ispitivana su 42 bolesnika, starosti preko 18 godina, sa dijagnozom: akutna mijeloidna leukemija (AML), akutna limfocitna leukemija (ALL), hronična limfocitna leukemija (HLL), mijelodisplastična/mijeloproliferativna neoplazma (MDS/MPN), Hočkinov limfom (HL), Nehočkinov limfom (NHL), koji su lečeni na Klinici za hematologiju UKCS, od decembra 2017. do novembra 2019. godine. Podaci o pacijentima dobijeni su uvidom u medicinsku dokumentaciju (Tabela 1).

\section{Mikrobiološke metode}

Nakon aloTMĆH, reaktivacija CMV je dokazivana kvantitativnom $P C R$ metodom, gde je određivan broj CMV DNK kopija po $1 \mathrm{ml}$ krvi.

\section{Terapija reaktivacije}

Reaktivacija CMV je definisana kao bilo koja vrednost viremije (broj kopija/1 ml krvi), dokazana kvantitativnom $P C R$ metodom, pri čemu su svi naši pacijenti imali preko 100 kopija CMV DNK na $1 \mathrm{ml}$ krvi. Reaktivacija CMV je lečena terapijskim dozama valganciklovira (Valcyte $\left.{ }^{R}\right)$ 2x900 mg po dve nedelje, uz smanjenje doza na $2 \times 450 \mathrm{mg}$ u narednom toku, ili ganciklovirom $\left(\right.$ Cymevene $\left.{ }^{R}\right) 2 \times 500 \mathrm{mg}$ iv dve nedelje, uz davanje anti CMV imunoglobulina $\left(\right.$ Cytotect $\left.^{R}\right) 50 \mathrm{mg}$ iv, na 2 nedelje, do negativizacije broja kopija CMV DNK. therapy [8]. The manifestations of CMV disease are the following: pneumonia, hepatitis, gastroenteritis, retinitis, and encephalitis, while the disease can develop as an early or late complication after the procedure [11].

The increasing success of antiviral therapy has decreased the incidence of $\mathrm{CMV}$ disease to approximately $10 \%$ in the first year after transplantation, however, the incidence of late $C M V$ reactivation has increased, since it has been established that antiviral therapy slows down the restoration of CMV-specific T-cell response. Mortality from CMV pneumonia is still high, approximately $70 \%$, while gastrointestinal CMV disease may manifest without detectible viremia, which makes it difficult to distinguish from gastrointestinal GvHD [12].

There is data in literature related to the protective role of early CMV reactivation against the relapse of myeloid leukemia, however, the same has not been proven for other hematologic neoplasms [13].

In this paper, we have compared CMV reactivation in relation to the serostatus of the donor and the recipient $(D / R)$, and we have analyzed whether there is a correlation between CMV status and the day of Le and $\mathrm{Tr}$ engraftment. We have also analyzed whether there is a greater frequency of CMV reactivation in the MAC (myeloablative conditioning) or in the RIC (reduced intensity conditioning) regimen, and whether there is greater frequency in match related donor (MRD) or match unrelated donor (MUD) allo-HSCT. The goal is also to determine whether CMV reactivation affects survival after allo-HSCT.

\section{METHODS}

This retrospective cohort study included 42 patients, above the age of 18 years, with one of the following diagnoses: acute myeloid leukemia (AML), acute lymphocytic leukemia (ALL), chronic lymphocytic leukemia (CLL), myelodysplastic/myeloproliferative neoplasm (MDS/MPN), Hodgkin lymphoma (HL), and Non-Hodgkin lymphoma (NHL), who were treated at the Clinic for Hematology of the Clinical center of Serbia, from December 2017 to November 2019. The data on the patients have been obtained from patient medical records (Table 1).

\section{Microbiology methods}

After allo-HSCT, CMV reactivation was proven with the quantitative PCR method, determining the number of CMV DNA copies per $1 \mathrm{ml}$ of blood.

\section{Reactivation therapy}

CMV reactivation is defined as any value of viremia (number of copies/1 $\mathrm{ml}$ of blood) proven with the quantitative PCR method. All of our patients, however, had more than 100 copies of CMV DNA per $1 \mathrm{ml}$ of blood. $\mathrm{CMV}$ reactivation was treated with therapeutic doses of 
Tabela 1. Kliničke forme oboljenja

Table1. Clinical forms of diseases

\begin{tabular}{lc}
$\begin{array}{l}\text { Dijagnoza } \\
\text { Diagnosis }\end{array}$ & $\begin{array}{c}\text { Broj pacijenata } \\
\text { Number of patients }\end{array}$ \\
$\begin{array}{l}\text { Hočkinov limfom } \\
\text { Hodgkin lymphoma }\end{array}$ & $9(21.43 \%)$ \\
\hline $\begin{array}{l}\text { Akutna mijeloidna leukemija } \\
\text { Acute myeloid leukemia }\end{array}$ & $14(33.33 \%)$ \\
\hline $\begin{array}{l}\text { Akutna limfocitna leukemij } \\
\text { Acute lymphocytic leukemia }\end{array}$ & $15(35.71 \%)$ \\
\hline $\begin{array}{l}\text { Mijelodisplastične/mijeloproliferativne neoplazme } \\
\text { Myelodysplastic/myeloproliferativeneoplasms }\end{array}$ & $2(4.76 \%)$ \\
\hline $\begin{array}{l}\text { Hronična mijeloidna leukemija } \\
\text { Chronic myeloid leukemia }\end{array}$ & $1(2.38 \%)$ \\
\hline $\begin{array}{l}\text { Nehočkinov limfom } \\
\text { Non-Hodgkin lymphoma }\end{array}$ & $1(2.38 \%)$ \\
\hline \begin{tabular}{l} 
Ukupno/Total \\
\hline
\end{tabular} & $\mathbf{4 2 ( 1 0 0 \% )}$ \\
\hline
\end{tabular}

\section{Statistička obrada}

Za statističku obradu podataka korišćen je softverski paket SPSS (Statistical Package for Social Sciences) za Windows, verzija 23.0. Statistička obrada je obuhvatila formiranje baze podataka sa grupisanjem i tabeliranjem podataka pacijenata koji su bili značajni za studiju. Deskriptivni statistički parametri su izraženi kroz: aritmetičku sredinu sa merama disperzije (SD, SE), medijanu, MOD i raspodele relevantnih frekvencija. Ukupno preživljavanje bolesnika je obuhvatilo period od momenta dijagnoze do smrtnog ishoda ili zaključno sa novembrom 2019. godine, kod živih pacijenata. Preživljavanje bolesnika u odnosu na lečenje je računato Kaplan-Meier-ovom metodom, a razlike u preživljavanju u kontekstu ispitivanih parametara ispitivani su Log Rank testom.

Na početku statističkog testiranja definisan je nivo značajnosti od 0,05 . Vrednosti koje su iznosile manje od 0,05 su smatrane statistički značajnim.

\section{REZULTATI}

Studijom je obuhvaćeno 42 pacijenta, prosečne starosti $37,83 \pm 11,36$ godina, u rasponu od 19 do 57 godina, u vreme sprovođenja procedure aloTMĆH. U vreme dijagnoze, prosečna starost je iznosila $35,19 \pm 12,02$ godina. Od 42 pacijenta, 21 je bio muškog pola i 21 ženskog pola (Tabela 2).

Bitan je bio odnos serostatusa recipijenta i donora (R/D), i utvrđeno je da je najučestalija kombinacija bila kada su i recipijent i donor bili CMV seropozitivni, što je utvrđeno kod 28 pacijenata (68,3\%). Kombinacija u kojoj je recipijent bio pozitivan, a donor negativan bilo je 10 (24,4\%). Kombinacija u kojoj je recipijent bio valganciclovir (Valcyte $\left.{ }^{R}\right)$ 2x900 mg for two weeks, with a lowering of the doses to $2 \times 450 \mathrm{mg}$ during further treatment, or with ganciclovir (Cymevene $\left.{ }^{R}\right) 2 \times 500 \mathrm{mg}$ iv, for two weeks, with the administering of anti-CMV immunoglobulin $\left(\right.$ Cytotect $\left.{ }^{R}\right) 50 \mathrm{mg}$ iv, every two weeks, until the nullification of the number of CMV DNA copies.

\section{Statistical analysis}

The SPSS (Statistical Package for Social Sciences) for Windows, version 23.0 was used for statistical analysis. Statistical analysis included the formation of a database with the grouping and tabular presentation of patient data relevant to the study. Descriptive statistical parameters have been expressed through the following: arithmetic mean with measure of dispersion (SD, SE), median, MOD, and the distribution of relevant frequencies. The overall survival (OS) of patients covered the period from the establishing of the diagnosis to the lethal outcome, or ending with November 2019, in living patients. Overall survival in relation to treatment was calculated with the Kaplan-Meier method, while the differences in survival in the context of the analyzed parameters were analyzed with the use of the Log Rank test.

At the beginning of statistical testing, the level of significance was defined at 0.05 . Values below 0.05 were considered statistically significant.

\section{RESULTS}

The study included 42 patients of the average age $37.83 \pm 11.36$ years, in the range of 19 to 57 years, at the time of the allo-HSCT procedure. At the time of diagnosis, the average age was $35.19 \pm 12.02$ years. Out of 42 patients, 21 were male and 21 were female patients (Table 2).

The relationship (ratio) between the serostatus of the recipient and donor (R/D ratio) was important, and it was determined that the most common combination was when both the recipient and the donor were CMV seropositive, which was found in 28 patients (68.3\%). There were 10 combinations of positive recipient and negative donor 10 (24.4\%). There were two

Tabela 2. Demografske karakteristike pacijenata

Table2. Demographic characteristics of patients

\begin{tabular}{lc}
\hline $\begin{array}{l}\text { Ukupan broj pacijenata } \\
\text { Total number of patients }\end{array}$ & $\mathbf{4 2}$ \\
Pol / Sex & \\
Žene / Women & $21(50 \%)$ \\
Muškarci / Men & $21(50 \%)$ \\
\hline Starost / Age & $37,83 \pm 11,36(19-57)$ years \\
\hline Sveukupno preživljavanje / Overall survival & $36,39 \pm 5,30$ months \\
\hline
\end{tabular}


Tabela 3. Odnos serostatusa recipijenta (R) i donora (D) i učestalost CMV reaktivacije u odnosu na serostatus $\mathrm{R} / \mathrm{D}$

Table3. Recipient-donor serostatus ratio and frequency of CMV reactivation in relation to the serostatus of the $R / D$

\begin{tabular}{|c|c|c|}
\hline $\begin{array}{l}\text { Serostatus } \\
\text { Serostatus } R / D \text { s }\end{array}$ & $\begin{array}{l}\text { Učestalost } \\
\text { Frequency }\end{array}$ & Procenat Percentage \\
\hline $\lg G+/+$ & 28 & $68,3 \%$ \\
\hline $\lg G+/-$ & 10 & $24,4 \%$ \\
\hline $\lg G-/+$ & 2 & $4,9 \%$ \\
\hline $\lg M+\lg G+/+$ & 1 & $2,4 \%$ \\
\hline Ukupno/Total & 41 & $100 \%$ \\
\hline $\begin{array}{l}\text { Serostatus R/D } \\
\text { Serostatus R/Ds }\end{array}$ & $\begin{array}{l}\text { Došlo do reaktivacije } \\
\text { Reactivation occurred }\end{array}$ & $\begin{array}{l}\text { Nije došlo do reaktivacije } \\
\text { Reactivation did not occur }\end{array}$ \\
\hline $\lg G+/+$ & $15(53.6 \%)$ & $13(46.4 \%)$ \\
\hline $\lg G+/-$ & $6(60.0 \%)$ & $4(40.0 \%)$ \\
\hline $\lg G-/+$ & $1(50 \%)$ & $1(50.0 \%)$ \\
\hline $\lg M+\lg G+/+$ & $0(0.0 \%)$ & $1(50.0 \%)$ \\
\hline Ukupno/Total & $22(53.7 \%)$ & $19(46.3 \%)$ \\
\hline
\end{tabular}

negativan, a donor pozitivan bilo je 2 (4,9\%). $U$ jednom slučaju je recipijent bio pozitivan i na IgM i na IgG antitela na CMV, pri čemu je i donor bio IgG pozitivan. $U$ jednom slučaju nedostajali su podaci o serostatusu recipijenta i donora (Tabela 3).

Napravili smo korelaciju između CMV reaktivacije sa odnosom serostatusa recipijenta i donora (R/D). U slučaju $\mathrm{R}+/ \mathrm{D}+$, reaktivacija se dogodila kod 15 pacijenata $(53,6 \%)$. Kada je CMV serostatus bio R+/D-, reaktivacija se dogodila kod 6 pacijenata $(60,0 \%)$. Kod odnosa CMV statusa R-/D+, kod jednog pacijenta je došlo do reaktivacije, dok kod drugog nije. $U$ onom jednom slučaju gde je dokazana pozitivnost na anti-CMV IgM antitela kod pacijenta, nije došlo do reaktivacije, odnosno nije detektovana virusna DNK (Tabela 3 ).

Tabela 4. Odnos serostatusa recipijenta (R) i donora (D) i učestalost CMV reaktivacije $u$ odnosu na serostatus $R / D$

\begin{tabular}{lccc}
\hline $\begin{array}{l}\text { Režim } \\
\text { Conditioning Regimen }\end{array}$ & $\begin{array}{l}\text { Došlo do reaktivacije } \\
\text { Reactivation occurred }\end{array}$ & $\begin{array}{l}\text { Nije došlo do reaktivacije } \\
\text { Reactivation did not occur }\end{array}$ & Ukupno/Total \\
\hline MAC & $19(63,3 \%)$ & $11(36,7 \%)$ & 30 \\
\hline RIC & $3(25,0 \%)$ & $9(75,0 \%)$ & 12 \\
\hline $\begin{array}{l}\text { Tip alogene transplantacije } \\
\text { Type of allogeneic transplantation }\end{array}$ & $\begin{array}{l}\text { Došlo do reaktivacije } \\
\text { Reactivation occurred }\end{array}$ & $\begin{array}{l}\text { Nije došlo do reaktivacije } \\
\text { Reactivation did not occur }\end{array}$ & \\
\hline MRD & $8(53,3 \%)$ & $7(46,7 \%)$ & 15 \\
\hline MUD & $8(42,1 \%)$ & $11(57,9 \%)$ & 19 \\
\hline
\end{tabular}

combinations where the recipient was negative, and the donor was positive 2 (4.9\%). In one case, the recipient was positive for both IgM and IgG CMV antibodies, while the donor was IgG positive. In one case, the data on the serostatus of the recipient and donor were missing (Table 3).

We established a correlation between CMV reactivation and the serostatus ratio between the recipient and donor (R/D). In case of $\mathrm{R}+/ \mathrm{D}+$, reactivation occurred in 15 patients (53.6\%). When the CMV serostatus was $\mathrm{R}+/ \mathrm{D}-$, reactivation occurred in 6 patients (60.0\%). When the CMV status relationship was R-/D+, reactivation occurred in one patient, while it did not occur in the other patient from this group. In the one case where anti-CMV IgM antibody positivity was proven, reactivation did not occur, i.e., viral DNA was not detected (Table 3).

Correlation between the number of CMV copies and Le engraftment $(p=0.031)$ was established, but not the correlation between the number of CMV copies and Tr engraftment ( $p=0.598)$.

Twelve patients underwent the RIC conditioning regimen (28.6\%), while 30 patients $(71.4 \%)$ underwent the MAC conditioning regimen. Of the 12 patients on the RIC regimen, reactivation occurred in 3 patients $(25.0 \%)$, while of the 30 patients on the MAC regimen, reactivation of the latent CMV infection occurred in 9 patients $(63.5 \%)$. Correlation was determined between the intensity of the conditioning regimen and CMV reactivation. Namely, reactivation in patients under the more intensive regimen, i.e., MAC was significantly more frequent $(p=0.025)$ (Table 4).

Of the 15 patients who had undergone MRD transplantation, reactivation occurred in 8 patients. In the patient subgroup with related allo-HSCT, in 8 patients, related haploidentical allo-HSCT was performed, but, due to the small number of patients in this group, we did not separate it from the rest of the MRD transplantations. MUD transplantation was performed in $19 \mathrm{pa}-$ tients, and, again, in 8 of them, reactivation of the CMV

Table4. Frequency of CMV reactivation in relation to the conditioning regimen and the type of allogeneic transplantation (MRD vs. MUD) 
Utvrđeno je da broj CMV kopija korelira sa engraftmentom Le $(p=0,031)$, ali korelacija sa engraftmentom Tr nije utvrđena $(p=0,598)$.

$R / C$ kondicionom režimu je podvrgnuto 12 pacijenata $(28,6 \%)$, a režimu MAC 30 pacijenata $(71,4 \%)$. Od 12 pacijenata koji su podvrgnuti RIC-u, kod 3 pacijenta $(25,0 \%)$ je došlo do reaktivacije, a od 30 pacijenata podvrgnutih MAC-u, kod 19 (63,5\%) je došlo do reaktivacije latentne CMV infekcije. Utvrđena je korelacija između intenziteta kondicionog režima i CMV reaktivacije. Naime, značajno češće je dolazilo do reaktivacije kod pacijenata koji su bili podvrgnuti jačem režimu, odnosno MAC-u $(p=0,025)$ (Tabela 4).

Od 15 pacijenata, kod kojih je obavljena MRD transplantacija, kod njih 8 je došlo do reaktivacije. U podgrupi pacijenata sa srodnom aloTMĆH, kod 8 pacijenata je urađena srodna haploidentična aloTMĆH, ali tu grupu, zbog malog broja pacijenata, nismo izdvajali od ostalih MRD transplantacija. MUD transplantacija je obavljena kod 19 pacijenata i opet je kod 8 došlo do reaktivacije CMV infekcije, iako korelacija između tipa transplantacije (MRD ili MUD) sa reaktivacijom CMV infekcije nije utvrđena $(p=0,515)$ (Tabela 4).

Sveukupno preživljavanje nakon aloTMĆH izračunato na osnovu Kaplan-Meier-ove studije na uzorku od 42 pacijenta je bilo 36,39 meseci $(95 \%$ Cl 26,0 - 46,78) (Grafikon 1). Srednja vrednost preživljavanja, ukoliko nije došlo do reaktivacije, je bila 39,57 meseci, a ukoliko je do nje došlo, srednja vrednost preživljavanja je bila 7,39 meseci ( $95 \%$ Cl 5,72 - 9,06) (Grafikon 2). Na osnovu Log Rank testa, nije utvrđeno da CMV reaktivacija utiče na preživljavanje $(p=0,527)$.

\section{DISKUSIJA}

U našoj studiji ispitivana su 42 pacijenta, od toga je bilo 21 žena i 21 muškarac, čija je prosečna starost u vreme sprovođenja procedure aloTMĆH iznosila $37,83 \pm 11,36$ godina. Distribucija dijagnoza je bila takva da je najviše pacijenata bilo obolelo od ALL, odnosno njih 15 (35,71\%), od AML 14 (33,33\%), od HL 9 (21,43\%), od MDS/MPN 2 (4,76\%), a po 1 pacijent od NHL i HLL (po 2,38\%).

Što se tiče distribucije CMV serostatusa, najviše je bilo R+/D+ kombinacija (68,3\%), 24,4\% je bilo R+/Dkombinacija, 4,9\% je bilo R-/D+ kombinacija, i bio je jedan slučaj pacijenta pozitivnog i na IgM i na IgG antitela, pri čemu je i donor bio pozitivan na lgG, ali u tom slučaju nije detektovana virusna DNK. Kada smo upoređivali učestalost reaktivacije sa CMV serostatusom recipijenata i donora, rezultati su pokazali sledeće: u slučaju $\mathrm{R}+/$ $D+$, reaktivacija se dogodila kod 15 pacijenata $(53,6 \%)$, kod R+/D-, reaktivacija se dogodila kod 6 pacijenata (60,0\%), u slučaju R-/D+, kod jednog pacijenta je došlo do reaktivacije. Iz toga zaključujemo da je najveća uče- infection occurred, although correlation between the type of transplantation (MRD or MUD) and the reactivation of CMV was not established $(p=0.515)$ (Table 4).

The overall survival after allo-HSCT, calculated on the basis of the Kaplan-Meier study, on a sample of 42 patients, was 36.39 months ( $95 \% \mathrm{Cl} 26.0$ - 46.78). The mean value for survival was 39.57 months, if there had been no reactivation, and it was 7.39 months, if reactivation had occurred ( $95 \% \mathrm{Cl} 5.72$ - 9.06) (Figure 1). On the basis of the Log Rank test, it was not determined that CMV reactivation affected survival $(p=0.527)$.

\section{DISCUSSION}

Our study analyzed 42 patients, 21 female and 21 male patients, whose average age at the time of the allo-HSCT procedure was $37.83 \pm 11.36$ years. The distribution of the diagnoses was such that the greatest number of patients was affected by ALL, i.e., 15 of them (35.71\%), 14 suffered from AML (33.33\%), 9 were afflicted with HL (21.43\%), two were MDS/MPN patients $(4.76 \%)$, and there was one patient suffering from $\mathrm{NHL}$ (2.38\%) and one affected by CLL (2.38\%).

As far as the distribution of the CMV serostatus is concerned, most of the combinations were $\mathrm{R}+/ \mathrm{D}+$ (68.3\%), 24.4\% were R+/D- combinations, $4.9 \%$ were $\mathrm{R}-/ \mathrm{D}+$ combinations, and there was one case of a patient who was positive for both IgM and IgG antibodies, while the donor was also IgG positive, though, in this case, viral DNA was not detected. When we compared reactivation frequency with the CMV serostatus of the recipients and donors, the results showed the

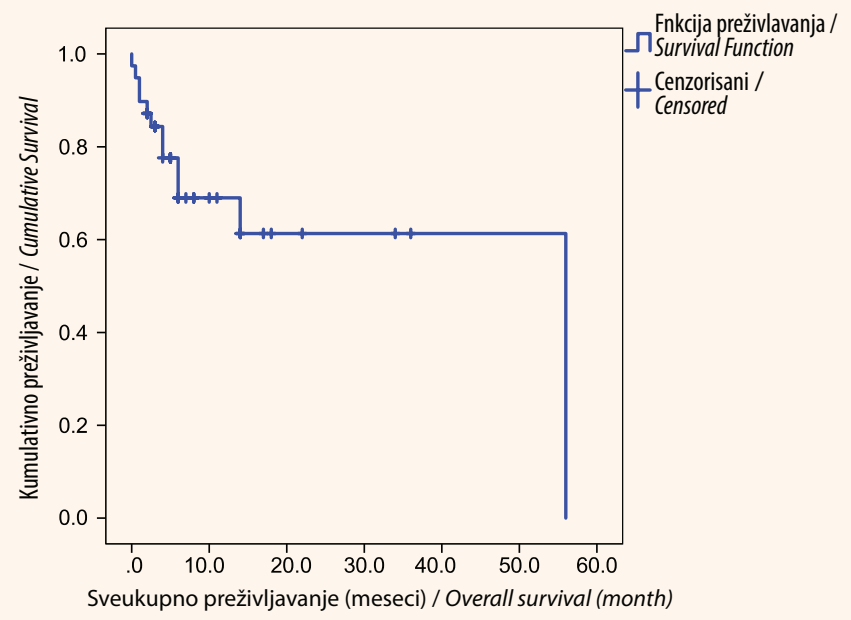

Grafikon 1. Sveukupno preživljavanje nakon alogene transplantacije matičnih célija hematopoeze

Figure 1. Overall survival after allogenic hematopoietic stem cell transplantation 


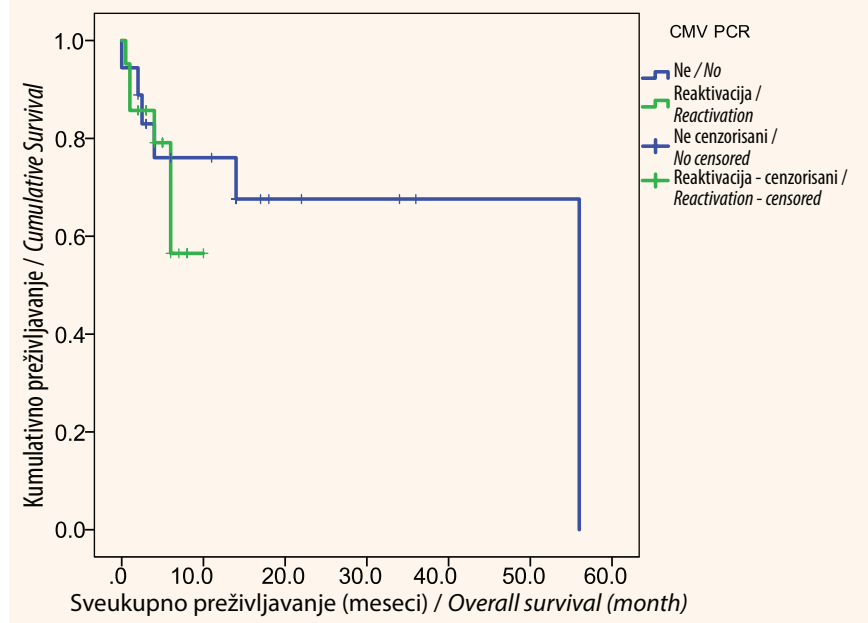

Grafikon 2. Preživljavanje u odnosu na CMV reaktivaciju

Figure 2. Survival in relation to CMV reactivation

stalost reaktivacije u slučaju kada je kombinacija R+/D-. Slične rezultate su dobili Džordž i saradnici, koji su svojih 315 pacijenata podelili u 3 grupe: grupu niskog rizika (R-/D-), grupu srednjeg rizika (R-/D+), i grupu visokog rizika za reaktivaciju (R+/D- ili R+/D+) [9]. Utvrdili su da je najveća incidencija bila u grupi visokog rizika, i iznosila je 53,3\% (11 pacijenata). Stern i saradnici visoku incidenciju reaktivacije u grupi sa $\mathrm{R}+/ \mathrm{D}+$ objašnjavaju ili reaktivacijom latentne CMV infekcije u ćelijama recipijenata ili/i reaktivacijom iz inficiranih ćelija donora prenetih graftom matičnih ćelija [8]. Najveća incidencija reaktivacije u grupi R+/D- se objašnjava odloženim CMV specifičnim imunskim odgovorom, zbog nedostatka T specifičnih ćelija u graftu $[8,14]$.

Naša studija je takođe ispitivala da li CMV reaktivacija utiče na engraftment Le i Tr. Utvrdili smo da postoji korelacija između broja kopija CMV DNK i engraftmenta Le $(p=0,031)$, ali korelacija sa engraftmentom $\mathrm{Tr}$ nije utvrđena $(p=0,598)$, što znači da reaktivacija CMV, ovde definisana preko detektovane viremije kvantitativnim PCR-om, odlaže prihvatanje kalema i rekonstituciju alogene hematopoeze u slučaju Le.

$R I C$ kondicioni režim je alternativa za pacijente kojima je aloTMĆH neophodna, ali postoje kontraindikacije za jači režim $(M A C)$, zbog komorbiditeta ili starije životne dobi [15]. U našoj studiji, pre transplantacije, MAC kondicionom režimu je bilo podvrgnuto 30 pacijenata $(71,4 \%)$, a RIC režimu 12 pacijenata $(28,6 \%)$. Kod naših pacijenata, reaktivacija se dogodila kod 19 pacijenata koji su bili podvrgnuti $M A C-u$ i kod 3 pacijenta koji su bili podvrgnuti $R I C-u$, čime smo pokazali da se CMV reaktivacija statistički značajno češće dešava ukoliko se koriste jači kondicioni režimi (MAC), odnosno da jačina kondicionog režima korelira sa brojem kopija virusne DNK. Studija koju su sproveli Pinjana i saradnici following: in case of $R+/ D+$, reactivation occurred in 15 patients $(53.6 \%)$, in $\mathrm{R}+/ \mathrm{D}-$, reactivation happened in 6 patients $(60.0 \%)$, in the case of R-/D+, reactivation occurred in one patient. This leads us to the conclusion that the highest reactivation frequency is in case of the R+/D- combination. Similar results were obtained by George et al., who divided their 315 patients, regarding the risk of $C M V$ reactivation, into the following three groups: the low-risk group (R-/D-), the medium-risk group (R-/D+), and the high-risk group (R+/D- or $R+/ D+)$ [9]. They established that the highest incidence of reactivation was in the high-risk group, amounting to $53.3 \%$ (11 patients). Stern et al. explained the high incidence of reactivation in the $\mathrm{R}+/ \mathrm{D}+$ group with either the reactivation of the latent CMV infection in the cells of the recipient or/and with reactivation from infected donor cells transplanted in the stem cell graft [8]. The highest incidence of reactivation in the R+/D- group is explained by the delayed CMV-specific immune response, due to the lack of T-specific cells in the graft $[8,14]$.

Our study also analyzed whether CMV reactivation affected Le and Tr engraftment. We found that there was a correlation between the number of CMV DNA copies and Le engraftment $(p=0.031)$, but correlation with Tr engraftment was not found $(p=0.598)$, which means that $C M V$ reactivation, defined here through viremia detected with quantitative $P C R$, delays graft acceptance and the reconstruction of allogenic hematopoiesis in the case of Le.

The RIC conditioning regimen is an alternative for patients who need allo-HSCT, but who have contraindications for the more intensive regimen (MAC), due to comorbidities or a more advanced age [15]. In our study, prior to transplantation, 30 patients $(71.4 \%)$ underwent the MAC conditioning regimen, while 12 patients underwent the RIC conditioning regimen (28.6\%). Amongst our patients, reactivation occurred in 19 patients who had undergone MAC and three patients who had undergone RIC, whereby we demonstrated that $C M V$ reactivation occurs statistically significantly more often when more intensive conditioning regimens are applied (MAC), i.e., that the intensity of the conditioning regimen correlates with the number of viral DNA copies. A study by Piñana et al. examined the effect of the RIC regimen on CMV reactivation and disease development in 195 patients. They established that reactivation occurred in $36.0 \%$ of patients [15].

In their cohort study, Nakamae et al. compared the incidence of reactivation against the MAC and RIC conditioning regimen and came up with different results. In fact, they demonstrated that, in conditioning regimens of reduced intensity, there was a lesser inci- 
je ispitivala uticaj $R I C$ režima na CMV reaktivaciju i razvoj bolesti kod 195 pacijenata. Utvrdili su da je kod $36,0 \%$ došlo do reaktivacije [15].

Nakamae i saradnici su u svojoj kohortnoj studiji upoređivali incidenciju reaktivacije $u$ odnosu na $M A C$ ili RIC kondicioni režim i došli su do različitih rezultata. Zapravo su pokazali da kod kondicionih režima slabijeg intenziteta postoji manja incidencija visokog viral load-a u odnosu na MAC, u prvih 100 dana nakon transplantacije, kao i da se CMV bolest kasnije javlja, ali značajne razlike u samoj incidenciji reaktivacije ili CMV bolesti između dva režima nije bilo. Oni pretpostavljaju da rezidualne T memorijske ćelije kod recipijenata koji su bili seropozitivni deluju zaštitno, u smislu da sprečavaju visoki viral load, sve dok ne dođe do potpunog himerizma, kada se više ne zapaža njihov zaštitni efekat [16].

Zlatni standard za aloTMĆH su HLA identični srodnici, što ovde označava MRD transplantacija. Ukoliko je graft uzet od HLA podudarnog, ali nesrodnog donora, radi se o MUD-u. Od 15 pacijenata kod kojih je obavljena MRD transplantacija, kod njih 8 je došlo do reaktivacije. MUD transplantacija je obavljena kod 19 pacijenata, i opet je kod 8 došlo do reaktivacije CMV infekcije, iako korelacija između tipa transplantacije (MRD ili MUD) sa reaktivacijom CMV infekcije nije utvrđena ( $p=0,515)$, u našoj studiji.

Do istih zaključaka došli su Jaskula i saradnici, u svojoj studiji u kojoj su upoređivali CMV reaktivaciju kod 71 pacijenta koji su graft dobili od nesrodnog donora, ali sa HLA podudarnošću 10/10 i kod 78 pacijenata koji su graft dobili od srodnika. U grupi nesrodnika, do reaktivacije je došlo kod 19 pacijenata, a u grupi srodnika kod 17 pacijenata, i nije nađena statistički značajna korelacija, ali, ukoliko je HLA podudarnost bila manja od 10/10, povećavala se incidencija reaktivacije $(p<0,08)[17]$.

Naša studija nije pokazala da CMV reaktivacija utiče na sveukupno preživljavanje. U stranoj literaturi se pominje zaštitni efekat $C M V$ reaktivacije na relaps, posebno u slučaju $A M L$, ali to ne utiče na poboljšanje sveukupnog preživljavanja [18]. Sa druge strane, retrospektivna studija Souse i saradnika je pokazala da je CMV infekcija značajno smanjila preživljavanje nakon transplantacije, te je medijana preživljavanja bila 16 meseci, ukoliko je došlo do reaktivacije, i 36 meseci, ako do reaktivacije nije došlo $(p=0,002)$ [19]. To se delimično objašnjava većom incidencijom infekcije usled mijelosupresije indukovane antivirusnom terapijom i usled akutnog GvHD [18].

Naša studija je imala više ograničenja. Obuhvatila je mali broj pacijenata, svega 42 , sa heterogenim dijagnozama, a sama analiza je vršena retrospektivno. dence of high viral load in relation to MAC, in the first 100 days upon transplantation, and that CMV disease occurred later, but that there was no significant difference in the incidence of reactivation itself, nor in CMV disease incidence, between the two regimens. They propose that residual memory T-cells act protectively in recipients who were seropositive, in the sense that they prevent high viral load, until complete chimerism occurs, after which their protective effect is no longer apparent [16].

The golden standard for allo-HSCT are HLA identical relatives, marked here as MRD transplantation. If the graft is taken from an HLA-matching, but unrelated donor, this is MUD. Out of 15 patients who underwent MRD transplantation, reactivation occurred in 8 of them. MUD transplantation was performed in 19 patients, and, again, reactivation of the CMV infection occurred in 8 of them, although correlation between the type of transplantation (MRD or MUD) and the reactivation of CMV infection was not established in our study $(p=0.15)$.

Jaskula et al. came to the same conclusion, in their study wherein they compared CMV reactivation in 71 patients who had received a graft from an unrelated donor, but with an HLA match of 10/10, with 78 patients, who had received a graft from a relative. In the unrelated group, reactivation occurred in 19 patients, whereas in the related group it occurred in 17 patients, and statistically significant correlation was not found, but, if the HLA match was below 10/10, the incidence of reactivation increased $(p<0.08)$ [17].

Our study did not show that CMV reactivation affected overall survival. International literature mentions the protective effect of CMV reactivation on relapse, especially in case of AML, but this has no influence on the improvement of overall survival [18]. On the other hand, a retrospective study by Sousa et al. showed that CMV infection significantly decreased survival after transplantation, so the median survival was 16 months, if reactivation occurred, and it was 36 months, if there was no reactivation $(p=0.002)$ [19]. This is partially explained by a higher incidence of infection due to myelosuppression induced by antiviral therapy and due to acute GvHD [18].

Our study had a number of limitations. It included a small number of patients, only 42 , who had heterogenous diagnoses, and the analysis itself was performed retrospectively.

\section{CONCLUSION}

CMV reactivation after allo-HSCT is still a frequent complication of this procedure, and is affected, to a great extent, by the serostatus ratio of the donor and 
ZAKLJUČAK CMV reaktivacija nakon aloTMĆH je i dalje česta komplikacija ove procedure i na nju u velikoj meri utiče serostatus donora i recipijenta (D/R). Najveća incidencija je u kombinaciji R+/D-, tako da izbor između seropozitivnog i seronegativnog donora jeste značajan za seropozitivnog recipijenta. CMV reaktivacija usporava engraftment Le, odnosno odlaže trenutak rekonstitucije alogene hematopoeze, tako da je odgovarajuća preventivna terapija, kod pacijenata koji su pod rizikom, neophodna (letermovir). Ista korelacija za Tr nije utvrđena. Izbor između MUD i MRD transplantacije nije značajan, u smislu reaktivacije latentne CMV infekcije. RIC kondicioni režim je u našoj studiji bio povezan sa manjom incidencijom reaktivacije. Takođe, nije utvrđen uticaj reaktivacije latentne CMV infekcije na sveukupno preživljavanje pacijenata.

\section{SPISAK SKRAĆENICA}

CMV- citomegalovirus

aloTMĆH- alogena transplantacija matičnih ćelija hematopoeze

HLA - human leukocyte antigens

GvDH (graft versus host disease) - bolest kalema protiv domaćina

$M A C$ - myeloablative conditioning

$R I C$ - reduced intensity conditioning

$M R D$ - match related donor

MUD - match unrelated donor

$\mathrm{AML}$ - akutna mijeloidna leukemija

ALL - akutna limfocitna leukemija

HLL - hronična limfocitna leukemija

MDS/MPN mijelodisplastične/mijeloproliferativne neoplazme

HL - Hočkinov limfom

NHL - Nehočkinov limfom

Sukob interesa: Nije prijavljen.

\section{LITERATURA / REFERENCES}

1. Azevedo LS, Pierrotti LC, Abdala E, Costa SF, Strabelli TM, Campos SV, et al. Cytomegalovirus infection in transplant recipients. Clinics (Sao Paulo). 2015 Jul;70(7):515-23.

2. Horowitz M. Data collection and management for hematopoietic stem cell transplant centers. Hematopoietic Stem Cell Transplantation: A Handbook for clinicians. Bethesda: AABB; 2009: 617-28.

3. Balint B, Todorović M. Matične ćelije-hemobiologija i terapijska primena. U Balint B., Trkuljić M, Todorović M. Osnovni principi hemoterapije. Beograd: Čigoja štampa; 2010: 257-335.

4. Chang L, Frame D, Braun T, Gatza E, Hanauer DA, Zhao S, et al. Engraftment syndrome after allogeneic hematopoietic cell transplantation predicts poor outcomes. Biol Blood Marrow Transplant. 2014 Sep;20(9):1407-17.

5. Gooley TA, Chien JW, Pergam SA, Hingorani S, Sorror ML, Boeckh M, et al. Reduced mortality after allogeneic hematopoietic-cell transplantation. N Engl J Med. 2010 Nov 25;363(22):2091-101. the recipient $(D / R)$. The highest incidence is in the $\mathrm{R}+/ \mathrm{D}$ - combination, which is why the choice between a seropositive and a seronegative donor is significant for a seropositive recipient. CMV reactivation slows down Le engraftment, i.e., it delays the moment of the reconstitution of allogenic hematopoiesis, which is why appropriate preventive therapy, in patients at risk, is necessary (letermovir). The same correlation was not established for Tr. The choice between MUD and MRD transplantation is not significant, in the sense of the reactivation of latent CMV infection. In our study, the RIC conditioning regimen was connected with a lesser reactivation incidence. Also, the effect of latent CMV infection reactivation on the overall survival of patients was not established.

\section{LIST OF ABBREVIATIONS AND ACRONYMS}

\author{
CMV - cytomegalovirus \\ allo-HSCT - allogenic hematopoietic stem cell transplantation \\ HLA - human leukocyte antigens \\ $\mathrm{GvDH}$ (graft versus host disease) \\ $M A C$ - myeloablative conditioning \\ $\mathrm{RIC}$ - reduced intensity conditioning \\ MRD - match related donor \\ MUD - match unrelated donor \\ AML - acute myeloid leukemia \\ ALL - acute lymphocytic leukemia \\ CLL - chronic lymphocytic leukemia \\ MDS/MPN - myelodysplastic/myeloproliferative neoplasm \\ HL - Hodgkin lymphoma \\ $\mathrm{NHL}$ - Non-Hodgkin lymphoma
}

Conflict of interest: None declared.

6. Tanaka Y, Kurosawa S, Tajima K, Tanaka T, Ito R, Inoue Y, et al. Analysis of non-relapse mortality and causes of death over 15 years following allogeneic hematopoietic stem cell transplantation. Bone Marrow Transplant. 2016 Apr;51(4):553-9.

7. Malagola M, Rambaldi B, Ravizzola G, Cattaneo C, Borlenghi E, Polverelli N, et al. Bacterial Blood Stream Infections Negatively Impact on Outcome of Patients Treated with Allogeneic Stem Cell Transplantation: 6 Years Single-Centre Experience. Mediterr J Hematol Infect Dis. 2017 Jun 20;9(1):e2017036.

8. Stern L, Withers B, Avdic S, Gottlieb D, Abendroth A, Blyth E, et al. Cytomegalovirus Latency and Reactivation in Allogeneic Hematopoietic Stem Cell Transplant Recipients. Front Microbiol. 2019 May 28;10:1186.

9. George B, Pati N, Gilroy N, Ratnamohan M, Huang G, Kerridge I, et al. Pre-transplant cytomegalovirus (CMV) serostatus remains the most important determinant of CMV reactivation after allogeneic hematopoietic stem cell transplantation in the era of surveillance and preemptive therapy. Transpl Infect Dis. 2010 Aug 1;12(4):322-9. 
10. Ljungman P, Perez-Bercoff L, Jonsson J, Avetisyan G, Sparrelid E, Aschan J, et al. Risk factors for the development of cytomegalovirus disease after allogeneic stem cell transplantation. Haematologica. 2006 Jan;91(1):78-83.

11. Boeckh $M$, Ljungman P. How we treat cytomegalovirus in hematopoietic cell transplant recipients. Blood. 2009; 113(23): 5711-19.

12. e la Cámara R. CMV in Hematopoietic Stem Cell Transplantation. Mediterr J Hematol Infect Dis. 2016 Jun 20;8(1):e2016031.

13. Green ML, Leisenring WM, Xie H, Walter RB, Mielcarek M, Sandmaier BM, et al. CMV reactivation after allogeneic HCT and relapse risk: evidence for early protection in acute myeloid leukemia. Blood. 2013 Aug 15;122(7):1316-24.

14. Cwynarski K, Ainsworth J, Cobbold M, Wagner S, Mahendra P, Apperley J, et al. Direct visualization of cytomegalovirus-specific T-cell reconstitution after allogeneic stem cell transplantation. Blood. 2001 Mar 1;97(5):1232-40.

15. Piñana JL, Martino R, Barba P, Margall N, Roig MC, Valcárcel D, et al. Cytomegalovirus infection and disease after reduced intensity conditioning allogeneic stem cell transplantation: single-centre experience. Bone Marrow Transplant. 2010 Mar;45(3):534-42.
16. Nakamae H, Kirby KA, Sandmaier BM, Norasetthada L, Maloney DG, Maris $M B$, et al. Effect of conditioning regimen intensity on CMV infection in allogeneic hematopoietic cell transplantation. Biol Blood Marrow Transplant. 2009 Jun;15(6):694-703.

17. Jaskula E, Bochenska J, Kocwin E, Tarnowska A, Lange A. CMV Serostatus of Donor-Recipient Pairs Influences the Risk of CMV Infection/Reactivation in HSCT Patients. Bone Marrow Res. 2012;2012:375075.

18. Peric Z, Wilson J, Durakovic N, Ostojic A, Desnica L, Vranjes VR, et al. Early human cytomegalovirus reactivation is associated with lower incidence of relapse of myeloproliferative disorders after allogeneic hematopoietic stem cell transplantation. Bone Marrow Transplant. 2018 Nov;53(11):1450-6.

19. Sousa H, Boutolleau D, Ribeiro J, Teixeira AL, Pinho Vaz C, Campilho F, et al. Cytomegalovirus infection in patients who underwent allogeneic hematopoietic stem cell transplantation in Portugal: a five-year retrospective review. Biol Blood Marrow Transplant. 2014 Dec;20(12):1958-67. 